\title{
Acute upper gastrointestinal bleeding in liver cirrhosis patients
}

\author{
Pavel Svoboda ${ }^{\mathrm{a}}$, Michal Konecny ${ }^{\mathrm{b}}$, Arnost Martinek ${ }^{\mathrm{a}}$, Vladimir Hrabovsky ${ }^{\mathrm{a}}$, Vlastimil Prochazka ${ }^{\mathrm{b}}$, Jiri Ehrmann ${ }^{\mathrm{b}}$
}

\begin{abstract}
Objectives. This study focuses on the etiology of acute upper gastrointestinal (GIT) bleeding in liver cirrhosis patients. Methods. A prospective examination of 137 liver cirrhosis patients with acute upper GIT bleeding. All patients underwent endoscopic examination and in the case of multiple findings, definition of the source of bleeding was based on the endoscopic report.

Results. The most frequent causes of acute bleeding were: oesophageal varices (57.7\%), peptic gastric and duodenal ulcers (18.2\%), portal hypertension gastropathy (9.5\%), gastric varices (5.1\%), reflux oesophagitis (2.9\%), Mallory-Weiss syndrome (2.9\%) and erosive gastropathy (1.5\%). A negative diagnosis was made in not more than $2.2 \%$ of patients. The majority of cases showed multiple findings in the upper digestive tract, each of which was a potential cause of bleeding. The mortality in all bleeding cirrhotic patients was $14.6 \%, 18.6 \%$ of which occurred in the varicose type of bleeding and $7.8 \%$ in the non-varicose type.

Conclusions. Portal hypertension led to bleeding caused by varices and portal hypertension gastropathy in $72.3 \%$ of patients, $62.8 \%$ of patients suffered from purely varicose bleeding and $37.2 \%$ from non-varicose bleeding. Early, detailed endoscopic examination leading to appropriate diagnosis and treatment is of paramount importance.
\end{abstract}

Key words: liver cirrhosis, portal hypertension, acute bleeding, peptic ulcer, endoscopy

Received: May 5, 2011; Accepted with revision: February 24, 2012; Available online: May 25, 2012 http://dx.doi.org/10.5507/bp.2012.029

anternal Medicine Clinic, University Hospital Ostrava and Faculty of Medicine, University Ostrava, Czech Republic

${ }^{b}$ Department of Internal Medicine II - Gastroenterology and Hepatology, University Hospital Olomouc and Faculty of Medicine and Dentistry, Palacky University Olomouc

Corresponding author: Pavel Svoboda, e-mail:pavel.svoboda@fno.cz

\section{INTRODUCTION}

Acute upper gastrointestinal bleeding is a serious medical problem in cirrhotic patients. The majority of published papers however, focus on varicose bleeding but quite a large number of cirrhotic patients bleed from other sources as well. Further, the dearth of information in the Czech medical literature over the past 20 years on this subject, has meant that many physicians assume only varicose bleeding in liver cirrhosis patients. This has also been our own experience over the years and prompted us to submit this report.

\section{Methodology}

Patients included all liver diagnosed cirrhosis patients hospitalized at the Internal Medicine Clinics of Ostrava and Olomouc University Hospitals for acute upper gastrointestinal bleeding in 2009 and 2010. They were monitored prospectively. All underwent tests to establish the etiology of the liver cirrhosis and determine the level of liver disease advancement expressed by the Child-Pugh classification. The diagnosis of portal hypertension was based on indirect signs. All patients underwent endoscopy of the upper GIT. In cases where the endoscopist found multiple lesions that could have possibly led to bleeding, the lesion $\mathrm{s} /$ he pointed out in the concluding report was established as the cause of the bleeding. Mortality during hospitalization was monitored.
The data were statistically analysed using the chisquared test of independence. With frequencies $\leq 5$, Fisher's exact test was used - a bilateral test, based on the use of interactions. However, both tests produced the same results at the 0.05 level ofsignificance.

\section{Group of patients}

The group included 137 patients, 90 (65.7\%) males and $47(34.3 \%)$ females. The age range was 35 to 83 years, mean 56.9. Range for men from 40 to 70 (average 55.8) and range for women from 35 to 83 (average 58) years. The etiology of the liver cirrhosis was alcohol 90 times (65.7\%), alcohol + viral hepatitis B 4 times (2.9\%), alcohol + viral hepatitis C 3 times $(2.2 \%)$, purely viral hepatitis B 10 times (7.3\%), only viral hepatitis C 13 times $(9.5 \%)$. Other causes included one case, i.e. $0.7 \%$ each of (autoimmune hepatitis, alpha-1-antitrypsin deficiency and hemochromatosis) and in 14 (10.2\%) no cause was identified. The Child-Pugh classification was established in all cases; the individual scores were: A 32 (23.3\%), B $70(51.1 \%)$ and C 35 (25.5\%). Portal hypertension was found in $125 / 137$ bleeding patients, or $91.2 \%$.

\section{RESULTS}

As expected, the most common source of bleeding was varices, in particular oesophageal varices, represented in 
$57.7 \%$ ( 79 cases). Gastric varices were present much less frequently ( 7 cases; $5.1 \%$ ). On the other hand, these are more difficult from the point of view of endoscopic examination and treatment owing to technically difficult visualisation in subcardial area, often due to inversion when there is a lot of blood in the stomach, and hence unclear terrain. For the same reasons ligation is also technically difficult. Due to sclerotization, the situation sometimes requires application of tissue adhesives with risk of further complications, and uncertain effect of compression using a balloon probe in the stomach. Overall, varicose bleeding represented a total of $86 / 137$ of all bleeding cases or $62.8 \%$.

Of the remaining $37.2 \%$ cases of bleeding, portal hypertension gastropathy was found in $9.5 \%$. This is not classed as "varicose" bleeding as varices are not involved in this case but it is a case of bleeding due to portal hypertension which includes bleeding from varices. If, from the morphological point of view, we classify them with non-varicose sources, then their share is just above one third. If we divide the patients into bleeding cases due to portal hypertension (from varices + portal hypertension gastropathy) and other causes, then they represent $27.7 \%$ of all bleeding cases in cirrhotic patients. We consider this finding very interesting but above all, important for clinical practice. Automatic assumption of bleeding from varices in cirrhotic patients could have serious consequences in about one third of patients because the therapeutic procedures vary - e.g. insertion of balloon probe in case of non-varicose source of bleeding could be ineffective.

The second most frequent cause of bleeding was peptic gastric and duodenal ulcers with a share of $18.2 \%$ (25 patients). These occurred more frequently than for instance gastric varices or portal hypertension gastropathy. There was almost a balance between gastric ulcers and duodenal ulcers (13:12; i.e. 52\%:48\%). Potential corre- spondence with the coincidence of portal hypertension or dependence on the level of advancement of the liver disease was monitored. $85 \%$ of ulcers bled "in the terrain" of portal hypertension. This meant that the endoscopist marked the ulcer as the bleeding source, instead of, for example, the coinciding varices or portal hypertension gastropathy. As regards the relation to Child-Pugh classification, the situation was as follows. We discovered that the risk of complications rises with the level of advancement of liver cirrhosis: in Child-Pugh A patients, 29.4\% of ulcers were bleeding, in Child-Pugh B patients it was $33.3 \%$ and in $\mathrm{C}$ patients $40.9 \%$. We can conclude that the risk of bleeding ulcers increases with incidence of portal hypertension and with degree of liver cirrhosis, although the trend is not statistically significant. The related thrombocytopenia and coagulopathy may have an influence. Thrombocytes ranged from 19 to 557, average 127 thousand and INR fluctuated between 0.9 and 3.9, average 1.6. Other risk factors/ etiological agents include Helicobacter pylori, which was proven in 9 ulcer cases (36\%), and NSAID which was used twice $(8 \%)$.

The other proven non-varicose sources included reflux oesophagitis (4 times, 2.9\%); Mallory-Weiss syndrome occurred with the same frequency, while erosions appeared twice $(1.5 \%)$. Three individuals $(2.2 \%)$ showed negative gastroscopy.

Mortality in all bleeding cirrhotic patients was $14.6 \%$, that is $20 / 137$ patients died. 16 patients (18.6\%) died of bleeding from varices, while only 4 patients $(7.8 \%)$ of bleeding from other sources. This difference does not reach statistic significance $(P=0.0846)$. An overview of individual sources and percentage of varicose and non varicose bleeding is provided in Table 1, Fig. 1.

Development of bleeding causes over was also evaluated. A total of 25 patients were re-hospitalized during the monitoring period for bleeding relapse. Table 2 shows

Table 1. Causes of acute upper gastrointestinal bleeding in liver cirrhosis patients within the monitored group and comparison with bibliography data.

\begin{tabular}{|c|c|c|c|}
\hline \multirow{3}{*}{$\begin{array}{l}\text { Source of bleeding } \\
\text { Total }\end{array}$} & \multicolumn{2}{|c|}{ Group } & \multirow{3}{*}{$\begin{array}{c}\text { Bibliography data } \\
\%\end{array}$} \\
\hline & $\mathrm{n}$ & $\%$ & \\
\hline & 137 & 100 & \\
\hline Oesophageal varices & 79 & 57.7 & $47.5\left(\right.$ ref. $\left.^{8}\right), 57\left(\right.$ ref. $\left.^{11}\right)$ \\
\hline Peptic gastric and duodenal ulcer & 25 & 18.2 & $\begin{array}{l}7.5\left(\text { ref. }^{7}\right), 8.5\left(\text { ref. }^{12}\right), 13.3\left(\text { ref. }^{11}\right) \\
\left.\left.13.8 \text { (ref. }^{9}\right), 14 \text { (ref. }^{10}\right), 16\left(\text { ref. }^{18}\right)\end{array}$ \\
\hline Portal hypertension gastropathy & 13 & 9.5 & $4{\left(\text { ref. }^{13}\right),}^{13} .5$ (ref. $\left.^{8}\right), 9.5$ (ref. $\left.^{7}\right)$ \\
\hline Gastric varices & 7 & 5.1 & 2.5 (ref. $\left.^{8}\right), 20.7\left(\right.$ ref. $\left.^{11}\right)$ \\
\hline Reflux oesophagitis & 4 & 2.9 & $1.7\left(\right.$ ref. $\left.^{7}\right)$ \\
\hline Mallory-Weiss syndrome & 4 & 2.9 & $2\left(\right.$ ref. $\left.^{10}\right), 3.8\left(\right.$ ref. $\left.^{12}\right)$ \\
\hline Erosive gastropathy & 2 & 1.5 & 3.9 (ref. $\left.^{7}\right), 4$ (ref. $\left.^{10}\right)$ \\
\hline Negative finding & 3 & 2.2 & $\begin{array}{l}\left.3\left(\text { ref. }^{7}\right), 6.5 \text { (ref. }^{11}\right) \\
\left.\left.14.8 \text { (ref. }^{9}\right), 16.6 \text { (ref. }^{10}\right)\end{array}$ \\
\hline
\end{tabular}




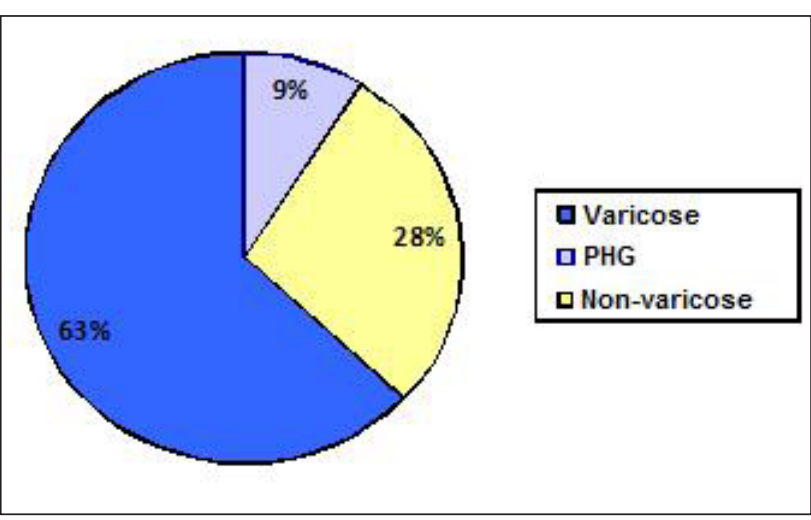

Fig. 1. Proportion of non-varicose and varicose bleeding.

that 14 patients had 2 bleeding attacks, 5 patients had 3 bleeding attacks, and 4, 5 and 6 bleeding attacks occurred in two patients each. It is apparent that the type of bleeding was not always the same. Only in $10(40 \%)$ patients, a similar type of source was reported in bleeding relapse; in others, the individual types alternated (varicose and non-varicose). Of the total number of 48 bleeding re- lapses, the source was the same in 26 cases $(54.2 \%)$, while in 22 cases $(45.8 \%)$ the type of bleeding was different.

\section{DISCUSSION}

In the "general" population, the most common cause of bleeding is peptic lesions of the upper digestive tract (up to $3 / 4$ ); varices comprise $8-10 \%$. Other findings are less frequent. Upper gastrointestinal bleeding recedes spontaneously or following conservative treatment in $80 \%$ of cases. Despite our diagnostic efforts, in up to $10 \%$ of cases, the source remains unidentified. Mortality does not exceed $10 \%$ (ref. $^{1}$ ).

These are statistics characterizing the general population. In the case of liver cirrhosis patients, mortality in the case of bleeding from oesophageal varices is unfortunately $30 \%$, to $70 \%$ (ref. $^{2}$ ), and is related to the degree of liver cirrhosis ${ }^{3,4}$. The cause of death is often multifactorial and closely correlates with the severity of liver damage. Varicose bleeding can stop spontaneously in up to $60 \%$ of cases, but bleeding relapse without treatment is high - $60 \%$ of patients experience new bleeding within a week of the first attack.

Table 2. Table of causes of bleeding relapses.

\begin{tabular}{|c|c|c|c|c|c|c|}
\hline \multirow[b]{2}{*}{ Patient } & \multicolumn{6}{|c|}{ Bleeding attack } \\
\hline & 1. & 2. & 3. & 4. & 5. & 6. \\
\hline 1. & VB & VB & & & & \\
\hline 2. & NB & VB & VB & VB & & \\
\hline 3. & NB & NB & & & & \\
\hline 4. & NB & NB & VB & & & \\
\hline 5. & VB & VB & NB & VB & VB & \\
\hline 6. & NB & VB & & & & \\
\hline 7. & NB & NB & VB & & & \\
\hline 8. & NB & VB & & & & \\
\hline 9. & NB & NB & & & & \\
\hline 10. & VB & NB & VB & VB & VB & VB \\
\hline 11. & VB & VB & & & & \\
\hline 12. & $\mathrm{VB}$ & $\mathrm{VB}$ & & & & \\
\hline 13. & VB & NB & NB & VB & NB & NB \\
\hline 14. & NB & VB & & & & \\
\hline 15. & VB & NB & VB & & & \\
\hline 16. & NB & VB & & & & \\
\hline 17. & VB & VB & & & & \\
\hline 18. & $\mathrm{VB}$ & $\mathrm{VB}$ & NB & & & \\
\hline 19. & VB & VB & & & & \\
\hline 20. & VB & NB & VB & VB & VB & \\
\hline 21. & VB & NB & NB & VB & & \\
\hline 22. & NB & NB & VB & & & \\
\hline 23. & VB & VB & & & & \\
\hline 24. & VB & VB & & & & \\
\hline 25. & VB & VB & & & & \\
\hline
\end{tabular}


On the basis of a number of criteria, the risk of death, risk of bleeding relapse and the need for urgent therapeutic intervention may be estimated in patients with acute upper gastrointestinal bleeding prior to endoscopy. The individual evaluating criteria include anamnesis of oesophageal varices, coagulopathy, thrombocytopenia, alcohol excess, abnormal liver function tests, i.e. circumstances related to liver cirrhosis ${ }^{5,6}$.

Varices are not the only source of bleeding in cirrhoses. The share in all bleeding cases has been found to be $57.7 \%$ for oesophageal varices and $5.1 \%$ for gastric varices, altogether $62.8 \%$ of cases. Other studies have come to the same conclusions. For example, D'Amico in his study of 465 cirrhotic patients, found varices to be the bleeding source in $72 \%$ of cases ${ }^{7}$. Odelowo et al. ${ }^{8}$ found bleeding varices in only $50 \%$ of cases, but his group was small (40 patients). Fassio ${ }^{9}$ mentions $52.5 \%$, and Gostout ${ }^{10}$ had an even smaller percentage of varicose bleeding - $47.3 \%$, despite the fact that his 300 sample size. On the other hand, Seo et al. ${ }^{11}$ reported the biggest percentage of varicose bleeding in $77.7 \%$ of cirrhotic patients. Kantorová et al. ${ }^{12}$ reported varicose bleeding in $74 \%$ of patients with liver cirrhosis, whereas the remaining $26 \%$ had a nonvaricose source. The average is $59.8 \%$, which is roughly our result of $62.8 \%$. Despite the fact that these studies slightly vary, we may conclude that varices are the most common cause, but in $1 / 4$ to $1 / 3$ of cases these patients bleed from a non-varicose source. Automatic assumption of bleeding from varices in cirrhotic patients, is misleading and this can have serious consequences in up to one third of patients as the treatment procedures are different.

According to the literature, the percentage of portal hypertension gastropathy in bleeding ranges from $4 \%$ (ref. ${ }^{13}$ ), $7.5 \%$ (ref. $^{8}$ ), 9.5\% (ref. $^{7}$ ). In our group it was $9.5 \%$.

The second most frequent cause of bleeding was peptic gastric and duodenal ulcers with a share of $18.2 \%$. These occurred more frequently than for instance gastric varices or portal hypertension gastropathy. The share of gastric ulcers and duodenal ulcers was virtually the same. In another study in patients with liver cirrhosis as well as with gastric and duodenal ulcerative lesions, we found; bleeding from the lesion in $35.2 \%$ of cases and that the risk rises with coincidence of portal hypertension and with degree liver cirrhosis ${ }^{14}$. In portal hypertension, there is splanchnic vasodilatation and arteriovenous shunts development in the submucosa which leads to increased blood flow in this area. This increases the risk of bleeding and at the same time decreases oxygenation of the mucosa with consequent risk of damage ${ }^{15,16}$. The related thrombocytopenia and coagulopathy may also be involved. Other risk factors/ etiological agents include Helicobacter pylori, which was found in these ulcers in $36 \%$ of cases and NSAID in $8 \%$ of cases. Certain influence can also be attributed to occurrence of hepatogenous ulcer and its frequent clinically silent progression, which leads to late diagnosis, and hence can present itself directly through a complication in the form of acute bleeding. Also Siringo et al. ${ }^{17}$ reported a single complication - bleeding in $20 \%$ of ulcers. In our study mentioned above, ulcers comprised $8.5 \%$ of bleeding cases in cirrhotic patients. A multicentre investigation by D'Amico ${ }^{7}$ diagnosed peptic ulcer as the cause in $7.5 \%$ of cases, Seo et al. ${ }^{11}$ in $13.3 \%$, Fassio et al. ${ }^{9}$ in $13.8 \%$, Gostout et al. ${ }^{10}$ in $14 \%$, and Thomas et al. ${ }^{18}$ in $16 \%$ of cases.

Other proven non-varicose sources included reflux oesophagitis (2.9\%); Mallory-Weiss syndrome occurred with the same frequency, while erosions appeared in $1.5 \%$ of cases. Less frequent causes of acute bleeding are: reflux oesophagitis $1.7 \%$ ( ref. $^{7}$ ), Mallory-Weiss syndrome $2 \%\left(\right.$ ref. $\left.^{10}\right)-3.8 \%$ (ref. $^{12}$ ) and erosive gastropathy $3.9 \%$ $\left(\right.$ ref. $\left.^{7}\right)-4 \%$ (ref. $\left.^{10}\right)$.

Despite diagnostic efforts, the bleeding source cannot always be defined. For upper gastrointestinal tract in cirrhotic patients, the cause is not defined only in $2.2 \%$ of cases, as opposed to the "general" population where the failure is estimated to occur in 10 or more \%. Our failure rate was significantly lower than in the published studies, where bleeding etiology was not discovered in $3 \%$ (ref. $^{7}$ ), $6.5 \%$ (ref. $^{11}$ ), $14.8 \%$ (ref. $^{9}$ ), and even in $16.6 \%$ (ref. ${ }^{10}$ ) of cases. We assume that the success rate could be influenced by several factors: clarity of the examined terrain (for this purpose we prefer insertion of nasogastric probe into the stomach plus its lavage prior to the endoscopic intervention), carefulness and experience of the endoscopist, repeated intervention following preparation of the patient after some time in case of failure of the first endoscopy.

One complicating factor is that these patients very often have multiple findings in the upper gastrointestinal tract ${ }^{19}$. Emphasis is hence given to the careful work of the endoscopist. Proof of oesophageal varices is not enough. It is necessary to look for another possible bleeding source- the right one.

A look at mortality is interesting as well. Acute upper gastrointestinal bleeding has been monitored in Ostrava University Hospital and Olomouc University Hospital for a long time. The total mortality of all bleeding types fluctuates around an average of $6 \%\left(\right.$ ref. $\left.{ }^{20}\right)$. For liver cirrhosis patients, the mortality of varicose bleeding is often reported in the literature but not the mortality of non-varicose bleeding in cirrhotic patients. In our group, mortality of varicose bleeding was $18.6 \%$, whereas with non-varicose sources it was $7.8 \%$. It is apparent that mortality of bleeding from non-varicose sources in cirrhotic patients is higher than in the "general" population. One reason for this difference may lie in the more frequent coincidence with portal hypertension and liver failure in the case of non-varicose bleeding in cirrhotic patients. On the other hand, the mortality of varicose bleeding is more than three times the mortality in "general" patients. Kantorová et al. ${ }^{12}$ described mortality of varicose bleeding in $20 \%$ cases and non-varicose sources in $11 \%$ cases. Another study ${ }^{7}$ distinguished the mortality of varicose and non-varicose bleeding within 5 days (9.2\% and 5.3\% respectively) and within 6 weeks (20.8\% and $14.9 \%)$. The data indicate the severity of varicose bleeding.

Monitoring the bleeding attacks in individual patients in the presented study showed the following. A total of 25 patients were re-hospitalized during the monitoring period for bleeding relapse and this was not always the same type 
of bleeding. Of the total 48 bleeding relapses, in $54.2 \%$ of cases the bleeding source was the same, while in $45.8 \%$ of cases the type of bleeding was different, which means that the varicose and non-varicose bleeding sources alternated. Kantorová et al. ${ }^{12}$ performed similar monitoring as well. However, they evaluated bleeding relapses only in patients with varicose bleeding in the anamnesis. $76 \%$ patients in their study had varicose bleeding again, whereas the remaining $24 \%$ showed a different (non-varicose) bleeding source. In our study in $69.2 \%$ of cases, varicose bleeding was followed by a varicose bleeding attack, whereas in $30.8 \%$ it was followed by bleeding from a non-varicose source.

\section{CONCLUSIONS}

In patients with acute upper gastrointestinal bleeding and liver cirrhosis, the most common source of bleeding was varices, in particular oesophageal varices $(57.7 \%)$, much less common was gastric varices $(5.1 \%)$. Varicose bleeding represented a total of $62.8 \%$ of all bleeding cases. Portal hypertension gastropathy was the cause in another $9.5 \%$ of cases. Bleeding due to portal hypertension, from varices + portal hypertension gastropathy, comprised $72.3 \%$ of all bleeding cases. The second most frequent cause of bleeding was peptic gastric and duodenal ulcers with a share of $18.2 \%$, with the proportion of gastric ulcers and duodenal ulcers being equal. The other proven non-varicose sources included reflux oesophagitis $(2.9 \%)$; Mallory-Weiss syndrome occurred with the same frequency, while erosions appeared in $1.5 \%$ of cases. In $2.2 \%$ of cases the source of the bleeding was not discovered during gastroscopy. Mortality in all bleeding cirrhotic patients was $14.6 \%, 18.6 \%$ of these were varicose bleeding and $7.8 \%$ non-varicose bleeding. It was found that in liver cirrhosis patients the types of bleeding sources in individual attacks alternated in $45.8 \%$ of cases, which implies alternation of varicose and non-varicose bleeding sources.

\section{ACKNOWLEDGEMENT}

The project was supported by the grant NS9754$3 / 2008$ provided by the Internal Grant Foundation of the Ministry of Health of the Czech Republic.

\section{REFERENCES}

1. Kumar R, Mills AM. Gastrointestinal bleeding. Emerg Med Clin North Am 2011;29(2):239-52.

2. Lata J. Krvácení z jícnových varixů. In: Lata J, Hulek P, Krajina A, Kral V, Safka V. Portální hypertenze při jaterní cirhóze a její důsledky. Plzeň: GAAN CZ; 2000. p. 41-55.

3. Husova L, Juranková J, Lata J, Senkyrík M, Príbramska V, Dastych M, Kroupa R, Kralova D. Bakteriální infekce ve vztahu ke vzniku a průběhu varikózního krvácení. Vnitř Lék 2007;53:1255-64.

4. Zhang $C$, Thabut D, Kamath PS, Shah VH. Oesophageal varices in cirrhotic patients: from variceal screening to primary prophylaxis of the first oesophageal variceal bleeding. Liver Int 2011;31(1):108-19.

5. Cameron EA, Pratap JN, Sims TJ, Inman S, Boyd D, Ward M, Middleton SJ. Three-year prospective validation of a pre-endoscopic risk stratification in patients with acute upper-gastrointestinal haemorrhage. Eur J Gastroenterol Hepatol 2002;14:497-501.

6. Husová L, Husa P, Ovesná P. Faktory ovlivňující přítomnost varixů a varikózního krvácení u pacientů s jaterní cirhózou. Vnitř Lék 2011;57:61-71.

7. D'Amico G, De Franchis R. Upper digestive bleeding in cirrhosis. Post-therapeutic outcome and prognostic indicators. Hepatology 2003;38:599-61.

8. Odelowo OO, Smoot DT, Kim K. Upper gastrointestinal bleeding in patients with liver cirrhosis. J Natl Med Assoc 2002;94:712-5.

9. Fassio E, Viudez P, Landeira G, Fernández N, Lattanzi M, Luis A. Upper digestive hemorrhage in liver cirrhosis: clinical and endoscopic findings. Acta Gastroenterol Latinoam 1992;22:181-6.

10. Gostout ChJ, Viggiano TR, Balm RK. Acute gastrointestinal bleeding from portal hypertensive gastropathy: prevalence and clinical features. Am J Gastroenterol 1993;88:2030-3.

11. Seo YS, Kim YH, Ahn SH, Yu SK, Baik SK, Choi SK, Heo J, Hahn T, Yoo TW, Cho SH, Lee HW, Kim JH, Cho M, Park SH, Kim BI, Han KH, Um SH. Clinical features and treatment outcomes of upper gastrointestinal bleeding in patiens with cirrhosis. J Korean Med Sci 2008;23:635-43.

12. Kantorova I, Svoboda J, Ochmann J, Kozumplik J, Marsová J. Duplicita zdroje krvácení u pacientů s jícnovými varixy. Rozhl Chir 1997;76:543-7.

13. Zaman A, Hapke R, Flora K, Rosen H, Benner K. Prevalence of upper and lower gastrointestinal tract findings in liver transplant candidates undergoing screening endoscopic evaluation. Am J Gastroenterol 1999;94:895-9.

14. Svoboda P, Ehrmann J, KIvana P, Machytka E, Rydlo M, Hrabovsky V. Hepatogenní vřed. Čes a Slov Gastroent a Hepatol 2007;61:249-53.

15. Hashizume M, Tanaka K, Inokuchi K. Morphology of gastric microcirculation in cirrhosis. Hepatology 1983;3:1008-12.

16. Sarfeh IJ, Soliman H, Waxman K, Coccia M, Rypins EB, Bui HX, Tarnawski A. Impaired oxygenation of gastric mucosa in portal hypertension. The basis for increased susceptibility to injury. Dig Dis Sci 1989;34:22.

17. Siringo S, Burroughs AK, Bolondi L, Muia A, Di Febo G, Miglioli M, Cavalli G, Barbara L. Peptic ulcer and its course in cirrhosis: an endoscopic and clinical prospective study. J Hepatol 1995;22:633-41.

18. Thomas E, Rosenthal WS, Rymer W, Katz D. Upper gastrointestinal hemorrhage in patiens with alcoholic liver disease and esophageal varices. Am J Gastroenterol 1979;72:623-9.

19. Svoboda P, Ehrmann J, KIvana P, Machytka E, Rydlo M, Hrabovsky V. Endoskopické nálezy $v$ horním trávicím traktu u pacientů s jaterní cirhózou. Vnitř Lék 2007;53:968-71.

20. Machytka E, Ehrmann J, Svoboda P, Klvana P, Martinek A. Dlouhodobé sledování pacientů s klinickými známkami krvácení do horní části trávicího traktu a negativním endoskopickým nálezem. Vnitř Lék 2007;53:942-6. 